TITLE:

\title{
Morphological and ecological adaptation of Basterotia bivalves (Galeommatoidea: Sportellidae) to symbiotic association with burrowing echiuran worms.
}

\section{AUTHOR(S):}

Goto, Ryutaro; Hamamura, Yoichi; Kato, Makoto

\section{CITATION:}

Goto, Ryutaro ... [et al]. Morphological and ecological adaptation of Basterotia bivalves (Galeommatoidea: Sportellidae) to symbiotic association with burrowing echiuran worms.. Zoological science 2011, 28(3): 225-234

ISSUE DATE:

2011-03

URL:

http://hdl.handle.net/2433/156510

RIGHT:

(c) 2011 Zoological Society of Japan 


\section{Morphological and Ecological Adaptation of Basterotia Bivalves (Galeommatoidea: Sportellidae) to Symbiotic Association with Burrowing Echiuran Worms}

Author(s) :Ryutaro Goto, Yoichi Hamamura and Makoto Kato

Source: Zoological Science, 28(3):225-234. 2011.

Published By: Zoological Society of Japan

DOI: http://dx.doi.org/10.2108/zsj.28.225

URL: http://www.bioone.org/doi/full/10.2108/zsj.28.225

BioOne (www.bioone.org) is a nonprofit, online aggregation of core research in the biological, ecological, and environmental sciences. BioOne provides a sustainable online platform for over 170 journals and books published by nonprofit societies, associations, museums, institutions, and presses.

Your use of this PDF, the BioOne Web site, and all posted and associated content indicates your acceptance of BioOne's Terms of Use, available at www.bioone.org/page/terms_of_use.

Usage of BioOne content is strictly limited to personal, educational, and non-commercial use. Commercial inquiries or rights and permissions requests should be directed to the individual publisher as copyright holder. 


\title{
Morphological and Ecological Adaptation of Basterotia Bivalves (Galeommatoidea: Sportellidae) to Symbiotic Association with Burrowing Echiuran Worms
}

\author{
Ryutaro Goto $^{1 *}$, Yoichi Hamamura ${ }^{2}$ and Makoto Kato ${ }^{1}$ \\ ${ }^{1}$ Graduate School of Human and Environmental Studies, Kyoto University, \\ Yoshida-Nihonmatsu-cho, Sakyo, Kyoto 606-8501, Japan \\ 214-16, Yakeyama Hibarigaoka-cho, Kure, Hiroshima 737-0901, Japan
}

\begin{abstract}
The burrows created by benthos in tidal flats provide various habitats to other organisms. Echiuran burrows are unique among these in being persistently disturbed by the host's undulating activity, but little is known on how symbionts adapt to such a unique habitat. We report here the morphological and ecological adaptation by two bivalve species of Basterotia (Sportellidae), including one new species, which are commensals with burrowing echiuran worms. The burrows of Ikedosoma gogoshimense were inhabited by Basterotia gouldi at intertidal gravelly mud flats in the central Seto Inland Sea, whereas those of Ochetostoma erythrogrammon were inhabited by Basterotia carinata n. sp. at an intertidal gravelly coral-sand flat at Amami-Ohshima Island. Both bivalve species were found embedded in the burrow wall with their posterior inhalant and exhalant apertures gaping to the burrow lumen, suggesting that they utilize the water currents created by host echiurans. The posteriorly robust, laterally inflated shell with developed carina is considered an adaptation to symbiotic life, as it is exposed to pressure caused by the host's persistent undulating activity. Females of Basterotia bivalves were larger than males, suggesting size-dependent sex change, and possessed brooded veligers in the ctenidium. Our findings suggest that species-specific intimate association with echiurans may be widespread among the Sportellidae bivalves, whose biology remains poorly understood.
\end{abstract}

Key words: adaptation, burrow, commensalism, ecosystem engineer, symbiosis, Echiura

\section{INTRODUCTION}

The echiuran worms (Phylum Echiura), commonly called "spoon worms" or "innkeeper worms", are marine invertebrates with sac- or sausage-like, non-segmented soft bodies and highly extensible proboscides (Ikeda, 1904; Stephen and Edomonds, 1972). Most species of echiuran worms excavate deep tunnels or burrows in soft sediments (Stephen and Edomonds, 1972; Nickell et al., 1995; Rogers and Nash, 1996). Because they pump water that is rich in food and oxygen through their burrows, which are protected from epibenthic predators, these are inhabited by various symbiotic organisms, including bivalves, polychaetes, crabs, shrimps, flatworms, nemerteans, nematodes, gastropods, copepods, entoprocts, and gobiid fishes (Anker et al., 2005; MacGinitie, 1935; Morton and Morton, 1983; Schembri and Jaccarini, 1978). Thus, it is thought that echiuran worms influence the abundance and distribution of diverse invertebrates in local habitats and function as ecosystem engineers, as do other burrowing animals in marine sedimentary environments, such as polychaete worms, sipunclid worms,

\footnotetext{
* Corresponding author. Phone: +81-75-753-6853;

Fax : +81-75-753-6694;

E-mail: gotoryu@ @2003.mbox.media.kyoto-u.ac.jp
} Supplemental material for this article is available online. doi:10.2108/zsj.28.225 and thalassinidean shrimps (Jones et al., 1994, 1997). The inside of an echiuran burrow is a unique environment, persistently disturbed by the peristaltic activity of the host

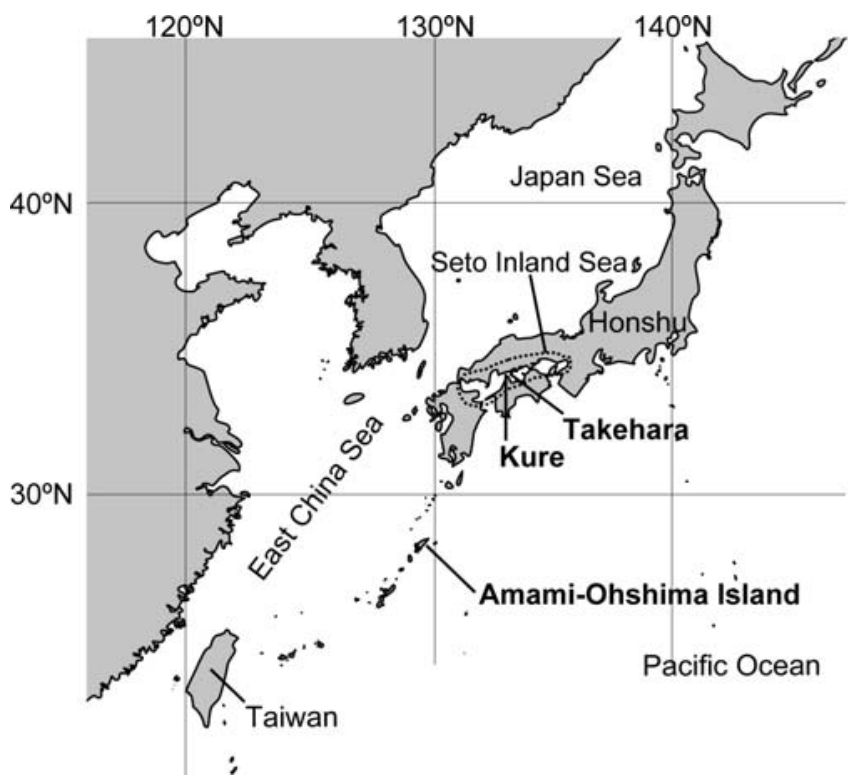

Fig. 1. Map showing the study sites: Kure, Takehara, and AmamiOhshima Island. 
(Anker et al., 2005). Therefore, to survive in echiuran burrows, symbionts may have to adapt morphologically or behaviorally to the pressure of the undulating movement of the host.

Among the diverse dwellers of echiuran burrows, only a few are obligate symbionts (Anker et al., 2005). In Bivalvia, only two galeommatoidean bivalve species, Pseudopythina ochestostomae (Lasaeidae) and Scintilla thalassemicola (Galeommatidae), are known to have strong associations with echiurans (Habe, 1962; Morton and Morton, 1983). The former is a small bivalve dwelling in the burrows of Ochetostoma erythrogrammon and Listriolobius sorbillans in Hong Kong and the Ryukyu Islands (Kosuge et al., 2003; Morton and Scott, 1989). The latter is a small bivalve that attaches to the body surface of Anelassorhynchus mucosus in the rocky intertidal zone in Amakusa, Japan (Habe, 1962). Identification of a new close association between echiuran worms and bivalves would provide a good opportunity for further understanding the evolution, adaptation, and specialization of bivalves to symbiotic association with echiuran worms.

Sportellidae is a small bivalve family, recently moved from Cyamioidea to Galeommatoidea owing to its molecular phylogeny (Campbell, 2000; Gribet and Distel, 2003; Taylor et al., 2007), and characterized by posterior inhalant and exhalant openings with very short siphons (Coan, 1999; Ponder, 1971). As living Sportellidae specimens previously have been rarely collected, their ecology and anatomy are not well known (Coan, 1999). However, several previous studies have suggested that some Basterotia species may have associations with other invertebrates. Kay (1979) briefly mentioned in her work that Basterotia angulata was found in the mud tubes of polychaete worms in tide pools in Hawaii, and Anker and colleagues (2005) reported that one specimen of an unidentified sportellid bivalve, possibly Basterotia sp., was collected from the burrow of an echiuran, O. erythrogrammon, in Venezuela. These fragmentary observations suggest that Basterotia may inhabit the burrows of annelid or echiuran worms.

Recently, we found two Basterotia species inhabiting echiuran burrows in the Japan Archipelago. To detect symbiotic associations with echiurans, we investigated their habitat, distribution, morphology, growth patterns, and reproductive biology. Their shell morphology and anatomical structure were very different from those of other galeommatoidean bivalves that are symbiotic with various benthic invertebrates. By comparing the characteristics of Basterotia bivalves with those of other galeommatoidean bivalves, we discuss their morphological and ecological adaptations to symbiotic asso-

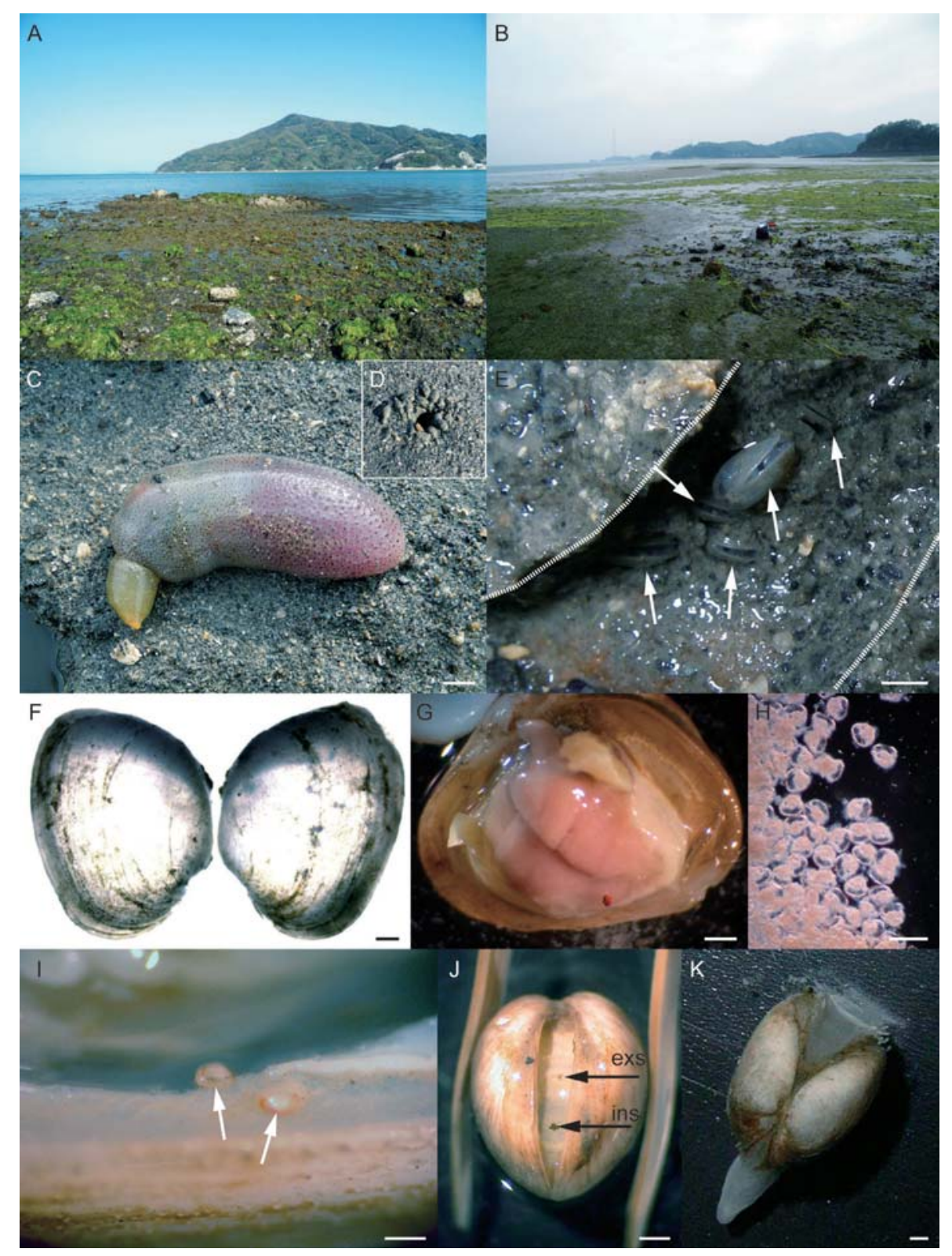

Fig. 2. Habitats, habits, and morphologies of the echiuran Ikedosoma gogoshimense (A-D) and its symbiotic bivalve Basterotia gouldi $(\mathbf{E}-\mathbf{K})$. (A, B) intertidal gravelly mud flats at Kure and Takehara; (C) a living echiuran; (D) entrance of an echiuran burrow around which mud dung is scattered; (E) symbiotic bivalves with their posterior parts gaping to the burrow lumen (white arrows and broken lines suggests bivalves and the echiuran burrow, respectively); (F) left and right valves illuminated by transmitted light (the shell of the posterior shaded part of both valves is thick); (G) an internal view of the right valve of a female brooding veligers in the ctenidium; (H) veliger larvae harbored in the ctenidium of a female; (I) juveniles attached to the inner ventral margin of the mantle of a female (white arrows); (J) posterior view of a living bivalve; (K) a creeping bivalve using its developed foot with its incurrent aperture expanded. Abbreviations: exs, exhalant siphon; ins, inhalant siphon. Scale bar: $1 \mathrm{~cm}(\mathrm{C}), 5 \mathrm{~mm}(\mathrm{E}), 1 \mathrm{~mm}(\mathrm{~F}, \mathrm{G}, \mathrm{I}, \mathrm{J}, \mathrm{K}), 0.1 \mathrm{~mm}(\mathrm{H})$. 
ciation with echiurans.

\section{MATERIALS AND METHODS}

\section{Study site and study species}

From June 2008 to June 2009, we sampled the sportellid bivalves of the intertidal zone at Kure $\left(34^{\circ} 12^{\prime} \mathrm{N}, 132^{\circ} 40^{\prime} \mathrm{E}\right)$ and Takehara $\left(34^{\circ} 19^{\prime} \mathrm{N}, 132^{\circ} 53^{\prime} \mathrm{E}\right)$ in the Seto Inland Sea and at Amami-Ohshima Island $\left(28^{\circ} 22^{\prime} \mathrm{N}, 129^{\circ} 25^{\prime} \mathrm{E}\right)$ in the East China Sea, Japan (Fig. 1). On the intertidal gravelly mud flats at Kure (Fig. 2A) and Takehara (Fig. 2B) are numerous burrows of two echiuran species, Ikedosoma gogoshimense (Echiuridae) (Fig. 2C) and Thalassema fuscum (Thalassematidae), with the former being more abundant than the latter. Ikedosoma gogoshimense is a species endemic to Japan and mainly occurs in the intertidal gravelly mud flats of the Seto Inland Sea. It is a deposit feeder that produces an L-shaped burrow with a vertical and a horizontal branch (Fig. 4A; Kawaguti, 1971). Around the entrance of the burrow, the echiurans scatter ellipsoidal mud particles (Fig. 2D; Supplemental material online). The scatterings of mud particles and the blind burrow suggest that the echiuran is a deposit feeder. The intertidal gravelly coral-sand flats of Amami-Ohshima Island harbored $O$. erythrogrammon (Thalassematidae) (Fig. $3 \mathrm{~A}, \mathrm{~B})$, which is a deposit feeder producing a U-shaped burrow very similar to those reported from Hong Kong (Morton and Morton, 1983). However, the echiuran burrows at our site were somewhat more horizontal than vertical, due to the presence of gravel in the sediment (Fig. 4B).

\section{Method}

At Kure and Takehara, we first searched for $I$. gogoshimense burrow entrances by examining the centrifuged scatterings of the ellipsoidal mud particles excreted by the echiurans (see Method in Kawaguti, 1971; Fig. 2D). After finding a burrow entrance, we carefully excavated the burrow and investigated the presence or absence of symbionts; if they were present, we recorded the number, position, and posture of each. Ikedosoma gogoshimense burrows collapsed easily because they were constructed in muddy sediments. To prevent bivalves from being overlooked, we sieved the mud collected from alongside the burrow using a 2-mm-mesh sieve.

At Amami-Ohshima Island, $O$ erythrogrammon usually produces burrows under rocks embedded in the sediment (Fig. 4B). Therefore we searched for their burrows by turning over rocks. When we found a burrow, we collected the echiurans with their symbionts. We also checked the number, position, and posture of any symbionts in each burrow. At all sites, we measured the volume of host

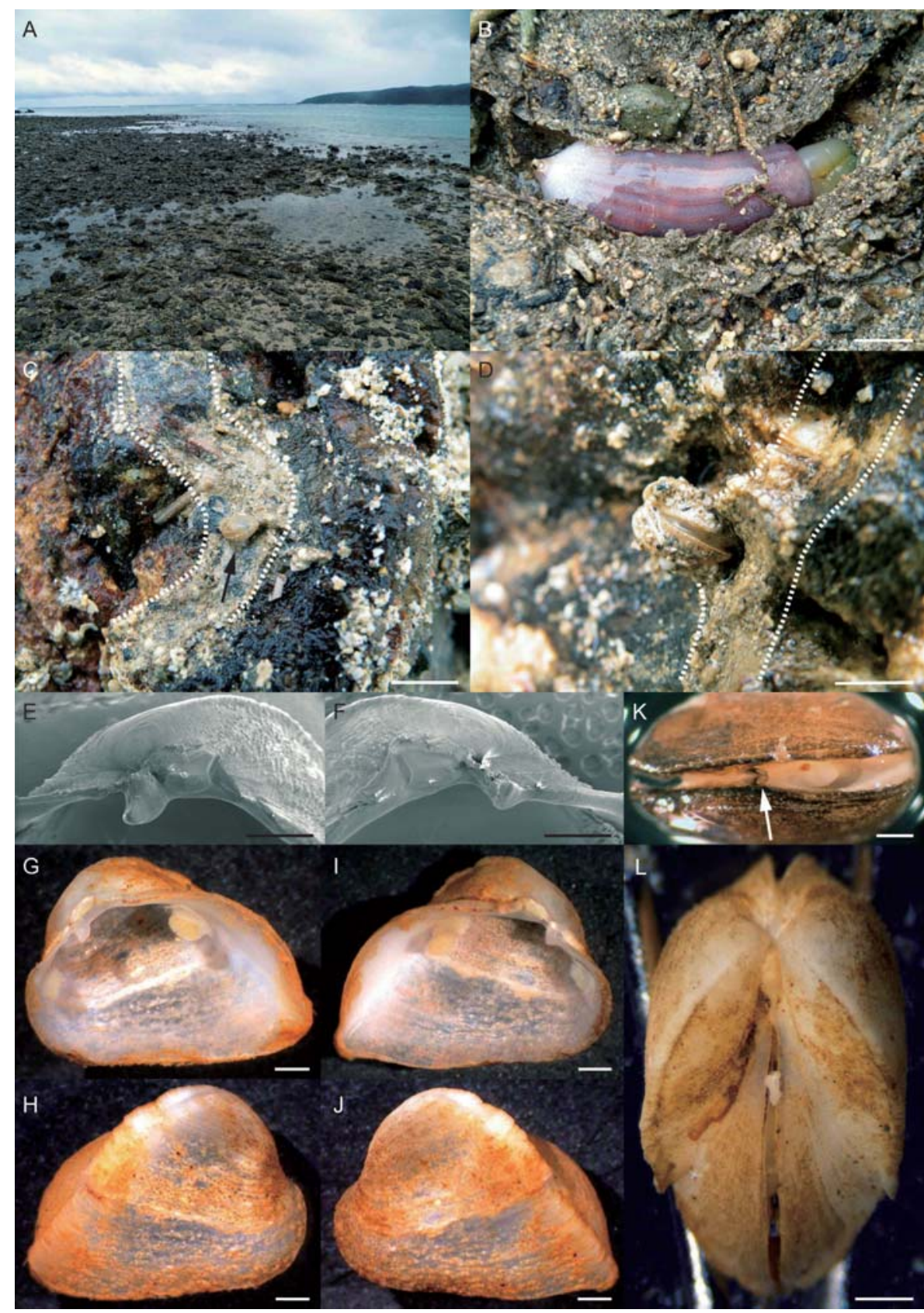

Fig. 3. Habitats, habits, and morphologies of the echiuran Ochetostoma erythrogrammon (A, B) and its symbiotic bivalve Basterotia carinata (C-L). (A) an intertidal gravelly, coral-sand flat at the type locality of Basterotia carinata at Amami-Ohshima Island; (B) an echiuran in its burrow; (C) a bivalve found in an echiuran burrow (a black arrow and white broken lines suggest a bivalve and the echiuran burrow, respectively); (D) the posture of a bivalve with its posterior part opening into the burrow lumen (white broken line suggests the echiuran burrow); $(\mathbf{E}, \mathbf{F})$ the hinge structure of the right and left valves; $(\mathbf{G}, \mathbf{H})$ internal and external views of the right valves; $(\mathbf{I}, \mathbf{J})$ internal and external views of the left valves; (K) ventral view of a living bivalve with juveniles (a black arrow) attached around the internal aperture of the mantle of a female bivalve; (L) posterior view of the bivalve. The Basterotia carinata in D, E-J and L is the holotype (NSMT-Mo 77014). Scales: $1 \mathrm{~cm}(B, C), 5 \mathrm{~mm}(D), 1 \mathrm{~mm}(E-L)$. 
A

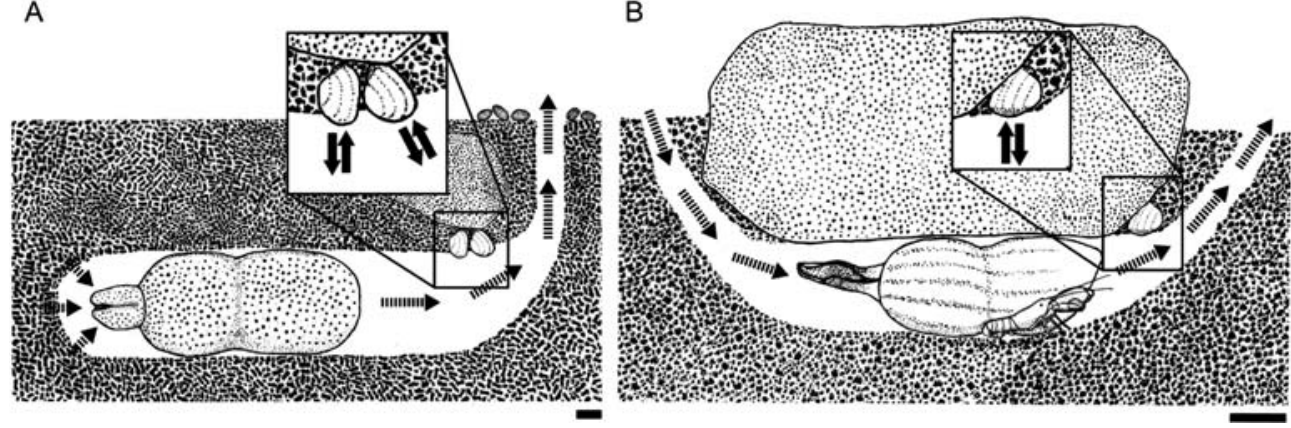

Fig. 4. Schematic representations of the habits of burrow-dwelling echiurans and their symbiotic bivalves (and a shrimp): (A) Ikedosoma gogoshimense occupied by Basterotia gouldi; (B) Ochetostoma erythrogrammon occupied by Basterotia carinata and a shrimp, Alpheus barbatus. Solid and broken arrows represent water currents created by the bivalves and their host echiurans, respectively. Scales: $1 \mathrm{~cm}(A, B)$.

A

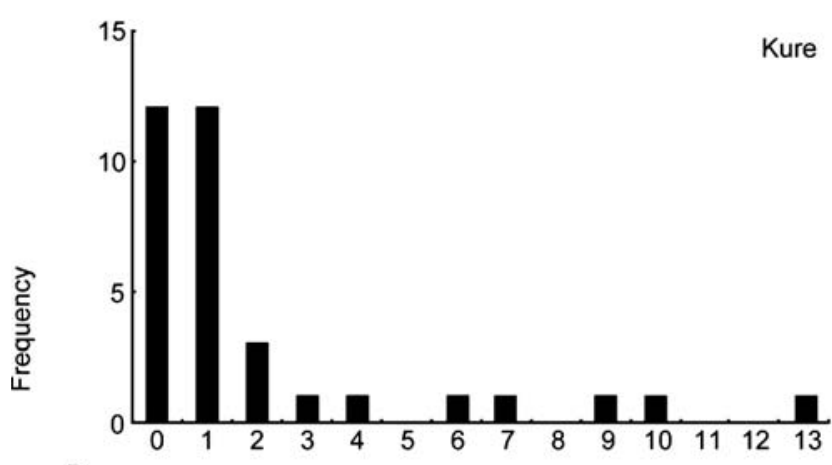

B

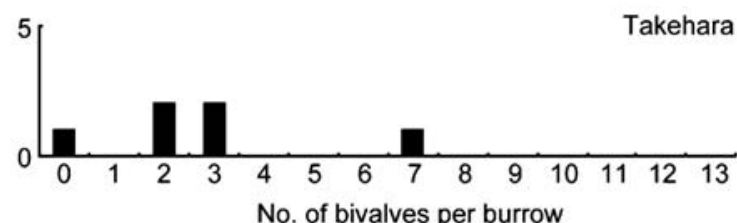

C

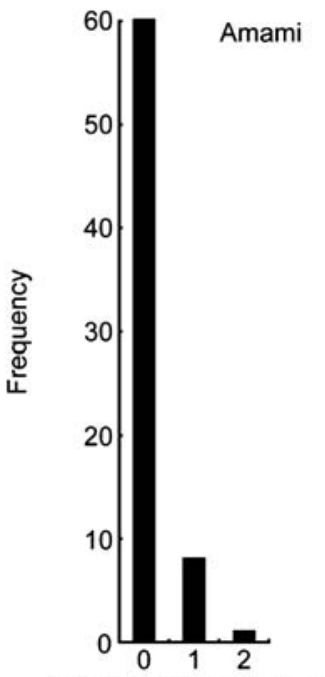

No. of bivalves per burrow

Fig. 5. Frequency distributions of symbiotic bivalves among echiuran burrows; Basterotia gouldi at Kure (A) and Takehara (B) and Basterotia carinata at Amami-Ohshima Island (C).

duced in the coral sand which is composed primarily of foraminiferal shells mixed with small fragments of seashells and dead corals. Therefore, we investigated the burrows of invertebrates produced in each substrate type. In the field, we first searched for burrow entrances on the surface of the tidal flat or under rocks. When burrows were found, we carefully dug each burrow and sieved the sand or mud collected from alongside the burrow using a 2-mm-mesh sieve.

To analyze Basterotia growth patterns, we measured shell length (antero-posterior), shell height (ventro-dorsal), and shell width (left-right). In addition, to understand the reproductive biology of these bivalves, we dissected $B$. gouldi, which were sampled during the period of 23-25 June 2009 at Kure, under a microscope to determine whether they were brooding veligers or juveniles, and whether their sexual organs contained eggs or sperm. Furthermore, to investigate the interaction between the echiurans and their symbiotic bivalves, we analyzed the relationships between echiuran volume and the number of bivalves per burrow, and that between echiuran volume and bivalve shell length.

\section{RESULTS}

\section{Host burrow use by symbiotic bivalves}

Twenty-two (64.7\%) of 34 Ikedosoma gogoshimense burrows in the gravelly mud flats at Kure harbored symbiotic bivalves did not live in habitats other than revealed that the (and, very rarely, Thalassema fuscum) burrows. The bivalve species were not found in the burrows of other sympatric invertebrates at the study sites (Table 1).

Among the 69 burrows of $O$. erythrogrammon observed at Amami-Ohshima Island, nine (13.0\%) harbored $B$. carinata (Fig. $5 \mathrm{C}$ ). Of these nine burrows, eight harbored one bivalve, and one harbored two bivalves whose shells touched each other. On average, one burrow harbored $0.14 \pm 0.05$ bivalves (range, $0-2$ ). All bivalves were attached by byssal threads to pebbles embedded in the burrow ceilings (Figs. 3C, D, 4B). Almost all parts of the bivalves were embedded in the burrow wall, with the posterior end opening into the burrow lumen (Figs. 3D, 4B). The results of an intensive search for the bivalves while turning over rocks and digging the burrows of other sympatric benthic invertebrates for a total of 18 hours strongly suggested that the bivalves do not live outside the echiuran burrows (Table 1).

\section{Interaction between echiurans and bivalves}

Figure 6 shows relationships between the biomass volume of echiurans and the number of symbiotic bivalves per 
Table 1. List of invertebrates excavated from burrows at the study sites, showing substratum type, numbers of burrows observed, and proportions of burrows containing Basterotia bivalves.

\begin{tabular}{|c|c|c|c|c|c|}
\hline Locality & Species & Class: Family & Substratum type & $\begin{array}{l}\text { No. of burrows } \\
\text { observed }\end{array}$ & $\begin{array}{c}\text { Prop. of burrows } \\
\text { containing Basterotia } \\
\text { bivalves (\%) }\end{array}$ \\
\hline \multirow[t]{10}{*}{ Kure } & Unidentified polychaete & Polychaeta: Terebellidae & muddy sand, mud & 40 & 0 \\
\hline & Sipunculus nudus & Sipunculidea: Sipunculidae & muddy sand & 1 & 0 \\
\hline & Siphonosoma cumanense & Sipunculidea: Sipunculidae & muddy sand & 20 & 0 \\
\hline & Ikedosoma gogoshimense & Echiura: Echiuridae & muddy sand, mud & 34 & 64.7 \\
\hline & Thalassema fuscum & Echiura: Thalassematidae & muddy sand, mud & 2 & 50.0 \\
\hline & Patinapta ooplax & Holothuroidea: Synaptidae & muddy sand & 40 & 0 \\
\hline & Protankyra bidentata & Holothuroidea: Synaptidae & mud & 40 & 0 \\
\hline & Nihonotrypaea japonica & Malacostraca: Callianassidae & muddy sand, mud & 20 & 0 \\
\hline & Nihonotrypaea harmandii & Malacostraca: Callianassidae & mud & 2 & 0 \\
\hline & Upogebia major & Malacostraca: Upogebiidae & mud & 1 & 0 \\
\hline \multirow[t]{10}{*}{ Amami-Ohshima Is. } & Unidentified polychaete & Polychaeta: Terebellidae & coral sand & 20 & 0 \\
\hline & Sipunculus nudus & Sipunculidea: Sipunculidae & coral sand & 2 & 0 \\
\hline & Siphonosoma cumanense & Sipunculidea: Sipunculidae & coral sand & 20 & 0 \\
\hline & Phascolosoma scolops & $\begin{array}{l}\text { Phascolosomatidea: } \\
\text { Phascolosomatidae }\end{array}$ & coral sand & 5 & 0 \\
\hline & Ochetostoma erythrogrammon & Echiura: Thalassematidae & coral sand & 69 & 13.0 \\
\hline & Patinapta ooplax & Holothuroidea: Synaptidae & coral sand & 50 & 0 \\
\hline & Polycheira rufescens & Holothuroidea: Chiridotidae & coral sand & 500 & 0 \\
\hline & Holothuria paradalis & Holothuroidea: Holothuriidae & coral sand & 10 & 0 \\
\hline & Nihonotrypaea japonica & Malacostraca: Callianassidae & coral sand & 20 & 0 \\
\hline & Upogebia carinicauda & Malacostraca: Upogebiidae & coral sand & 3 & 0 \\
\hline
\end{tabular}

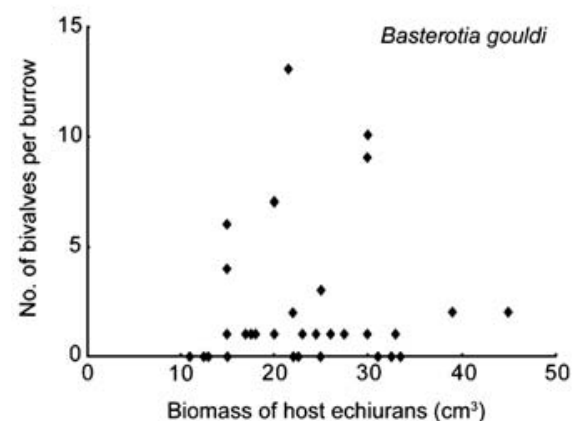

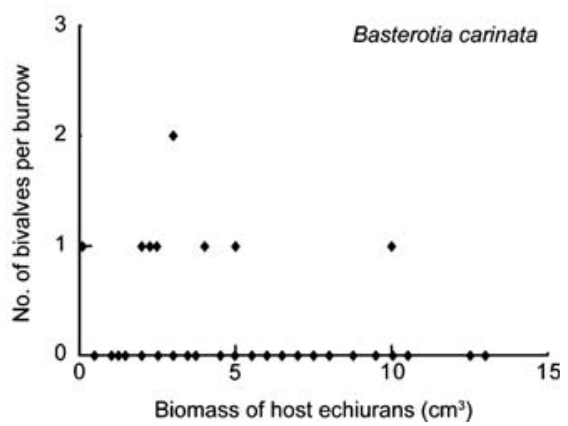

Fig. 6. Relationships between the biomass volume of host echiurans and the number of symbiotic bivalves per burrow. Basterotia gouldi symbiotic with Ikedosoma gogoshimense at Kure (A) and Basterotia carinata symbiotic with Ochetostoma erythrogrammon at Amami-Ohshima Island (B).

burrow (Fig. 6A: I. gogoshimense and B. gouldi at Kure; Fig. 6B: O. erythrogrammon and B. carinata at AmamiOhshima Island). No significant correlations were detected between parameters (Spearman's rank correlation test: $B$. gouldi, $\rho=0.107, p=0.554 ; B$. carinata, $\rho=0.123, p=$ 0.315).

Figure 7 shows relationships between the biomass volumes of echiurans and the average shell length of symbiotic bivalves in each burrow, and that between the biomass volumes of echiurans and the shell length of the largest bivalve in each burrow (Fig. 7A, C: I. gogoshimense and B. gouldi; Fig. 7B, D: O. erythrogrammon and $B$. carinata). No significant correlations were detected between parameters (Spearman's rank correlation test: host volume-average shell length, $B$. gouldi, $\rho=0.246, p=0.270 ; B$. carinata, $\rho=$
0.352, $p=0.356$; host volume-shell length of the largest bivalve, $B$. gouldi, $\rho=0.325, p=0.140 ; B$. carinata, $\rho=0.067, p=0.865$ ).

\section{Morphology, morphometry, and anatomy of bivalves}

B. gouldi have ovate shells with a very thick posterior part (Fig. $2 \mathrm{~F}$ ), whereas $B$. carinata have ovatetrigonal shells with a strong carina running from the umbo to the postero-ventral margin (Fig. 3G-J). The shells of both species were equivalve and had large posterior and small anterior gapes, even when the valves were tightly closed (Figs. $2 \mathrm{~J}$, $3 \mathrm{~L})$. The posterior gapes of $B$. gouldi were larger than those of $B$. carinata (Figs. $2 \mathrm{~J}, 3 \mathrm{~L}$ ). The ratios of shell height to shell length and shell width to shell length were plotted against shell length (Fig. 8), and the results showed that the symbiotic bivalves grew with their lateral shell morphometry unchanged (Spearman's rank correlation test: $B$. gouldi, $\rho=0.018, p=0.884 ; B$. carinata, $\rho=$ $0.246, p=0.489$; Fig. $8 A, C)$, whereas their relative shell width increased ontogenetically $(B$. gouldi, $\rho=0.725, p<$ $0.0001 ; B$. carinata, $\rho=0.673, p=0.033$; Fig. $8 B, D)$.

The internal anatomy of $B$. gouldi and $B$. carinata is shown in Fig. 9. Although the shell shape of these species is quite different, their internal anatomy is very similar. Both bivalve species have very short inhalant and exhalant siphons at their posterior ends. The posterior mantle has numerous small, well-developed tentacles around the inhal- 


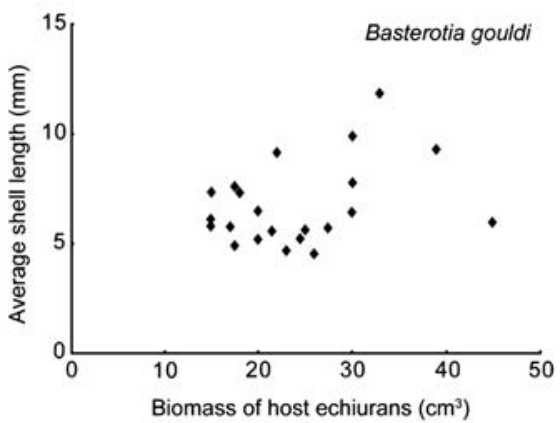

C

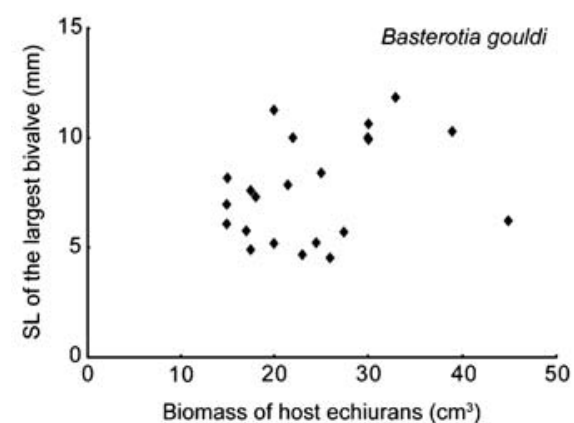

B

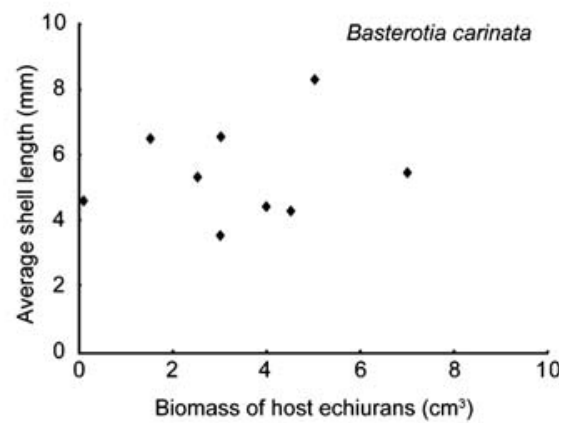

D

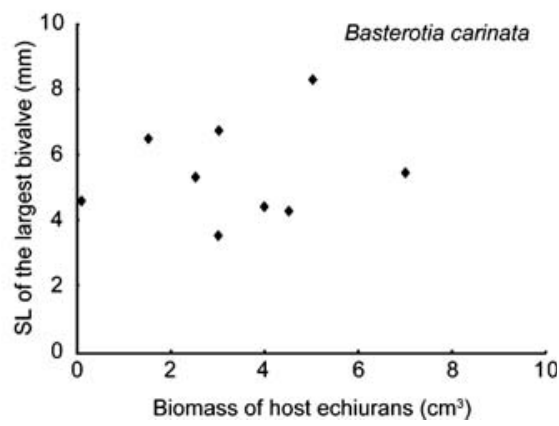

Fig. 7. Relationships of the biomass volume of host echiurans to average shell length of symbiotic bivalves dwelling in each burrow $(\mathbf{A}, \mathbf{B})$ and to shell lengths $(S L)$ of the largest bivalves (C, D). Basterotia gouldi at Kure (A, C) and Basterotia carinata at Amami-Ohshima Island (B, D).
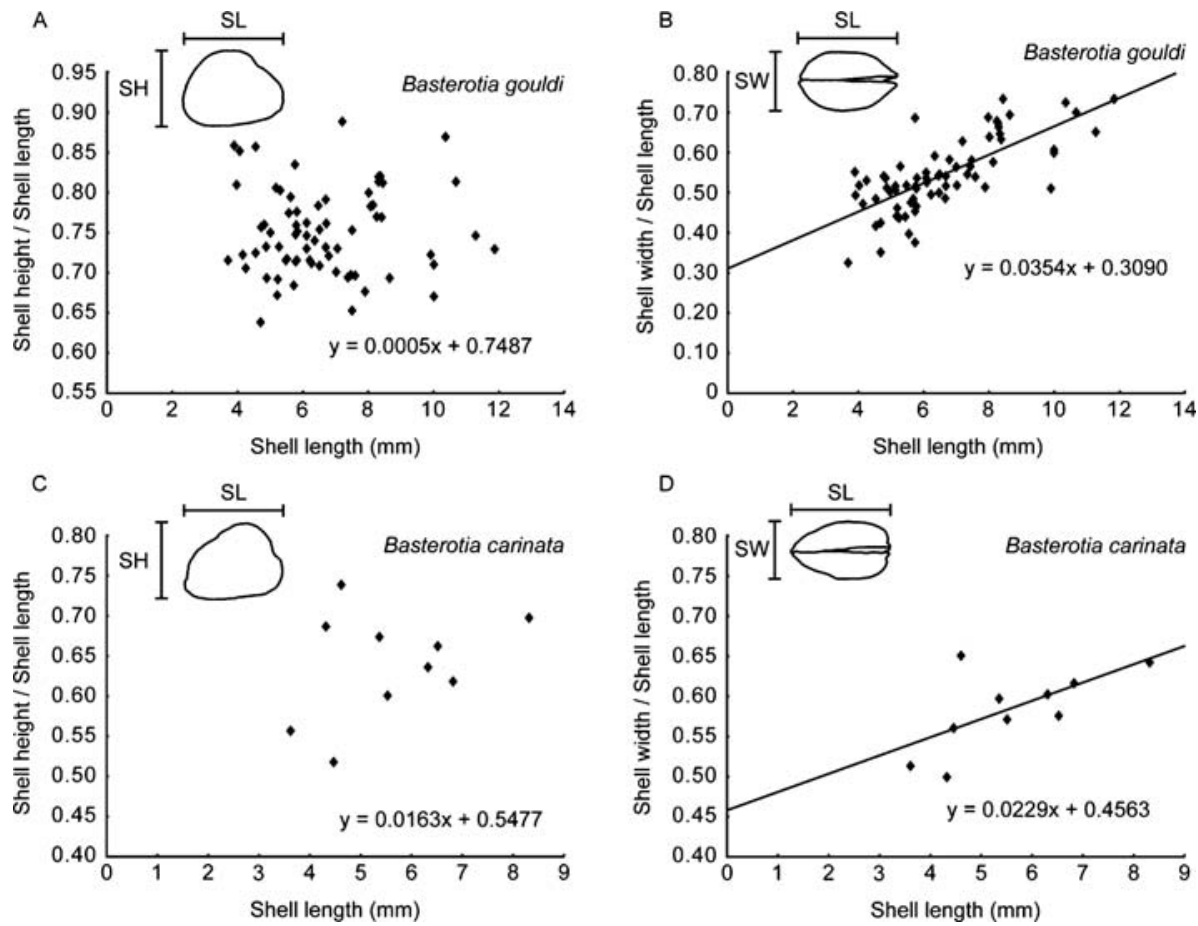

Fig. 8. Relationships of shell length to shell height/shell length ratio (A, C) and to shell width/ shell length ratio (B, D). Basterotia gouldi at Kure (A, B), and Basteoria carinata at AmamiOhshima Island (C, D).

ant and exhalant pallial apertures. The foot has byssal glands with fine, transparent byssal threads. The anteroventral side of the mantle has an aperture through which the foot is extended. The outer demibranch is smaller than the inner. The anterior and posterior adductor muscles are ovate and subequal, with the anterior being slightly smaller than the posterior. The digestive gland is brown, and is located anterior to the large, white gonad.

\section{Reproductive biology and sexual composition of bivalves among burrows}

In total, we dissected $40 \mathrm{~B}$. gouldi bivalves collected from 12 burrows at Kure. Of these 40 individuals, eight were females, 14 were males, and 18 were immature or intermediate (i.e., individuals that did not exhibit any gonad development) (Fig. 10). Mature sperm were detected in smaller individuals (shell length; $7.0 \pm 0.3 \mathrm{~mm}$, range, 6 $10 \mathrm{~mm}$ ), whereas mature ova were detected in larger specimens (shell length; $9.2 \pm 0.4 \mathrm{~mm}$, range, 7-12 $\mathrm{mm}$ ). The shell lengths of mature females were significantly greater than those of mature males ( $t$-test, $P<0.0001$; Fig. 9). Some females were brooding veliger larvae in the ctenidium (Fig. 2G, H), and juveniles with shell lengths of 1-2 $\mathrm{mm}$ were found in the ventral margins of the mantle cavities (Figs. 2l, 3K, 9). These small bivalves contained neither sperm nor ova. Of the eight females, one was brooding hundreds of veliger larvae and five juveniles, three brooded a single juvenile, and four brooded neither veliger larva nor juveniles. We also found one juvenile attached to the ventral mantle margin of a male.

Of 12 burrows, five harbored males and females, one harbored only males, and six harbored only immature individuals (Fig. 11). Among the burrows that harbored at least one male and one female, the maleto-female ratio was $1.86 \pm 0.79$ males to 1 female on average.

\section{The symbiont community in echi-} uran burrows

A list of symbionts dwelling in the echiuran burrows is provided in Table 2. In addition to $B$. gouldi, we found a small gastropod species Macromphalus tornatilis (Vanikoridae) and a small crab species Pinnixa sp. (Pinnotheridae) inhabiting the burrow of $I$. gogoshimense. 


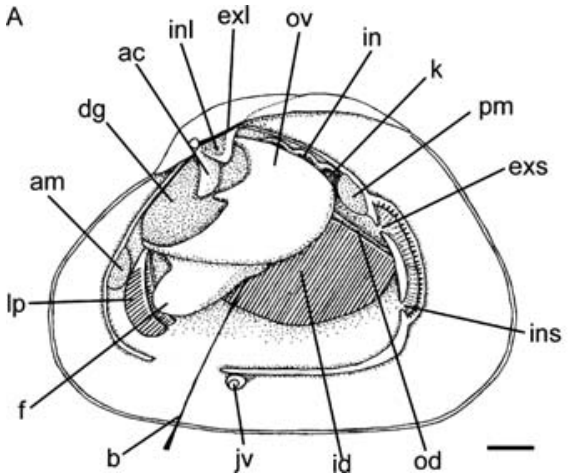

B

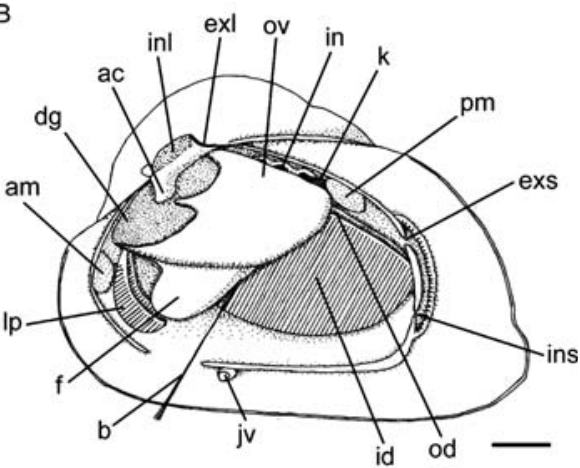

Fig. 9. Internal anatomy of the right parts of females of Basterotia gouldi (A) and B. carinata (B). Abbreviations: ac, anterior cardinal tooth; am, anterior adductor muscle; b, byssus; dg, digestive grand; exl, external ligament; exs, exhalant siphon; $f$, foot; id, inner demibranch; in, intestine; inl, internal ligament; ins, inhalant siphon; jv, juvenile; Ip, labial palp; od, outer demibranch; ov, ovary; pm, posterior adductor muscle; k, kidney. Scales: $1 \mathrm{~mm}(\mathrm{~A}, \mathrm{~B})$.

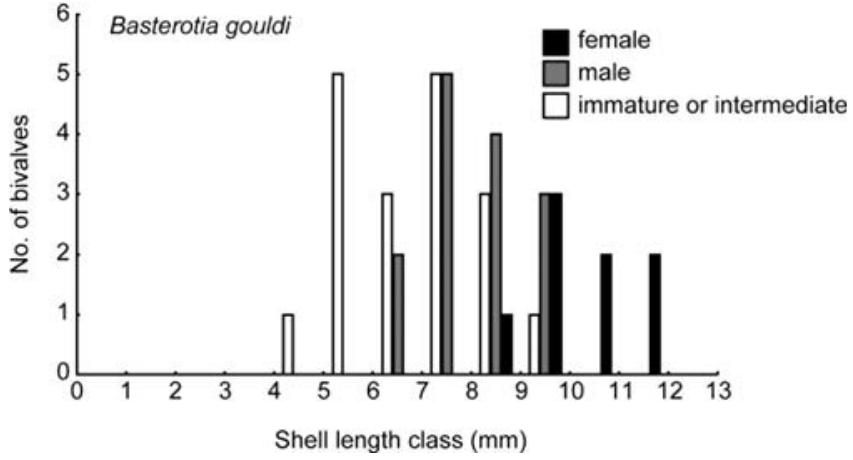

Fig. 10. Size distribution of Basterotia gouldi bivalves sorted by gravidity and sex.

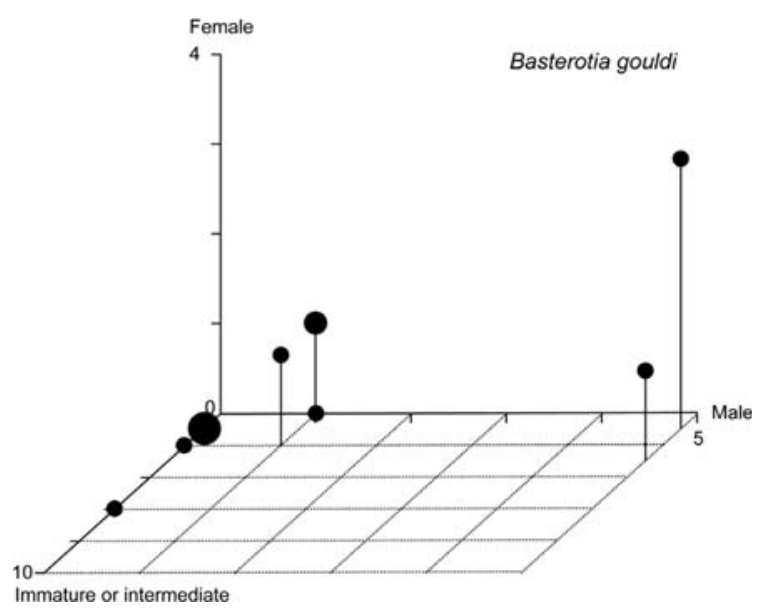

Fig. 11. Composition of sexes of Basterotia gouldi in each echiuran burrow. Symbol sizes are proportional to sample size.

M. tornatilis attached to the pebbles embedded in the burrow wall, and one specimen was found on the shell of a living $B$. gouldi. In $O$. erythrogrammon burrows, a small snapping shrimp species, Alpheus barbatus, was almost always found, and unidentified scale worms and phenacolepadid snails were sometimes found. $A$. barbatus and the scale worms were usually positioned behind the echiuran body, whereas the phenacolepadid snails attached to rock embedded in the burrow wall. None of these symbiotic organisms was found outside the host echiuran burrows.

\section{Species description}

Family Sportellidae Dall, 1899

Genus Basterotia Mayer, in Hörnes, 1859

Basterotia carinata Goto, Hamamura and Kato n. sp.

[New Japanese name: Hainumikazegai]

Holotype: NSMT-Mo 77014, Shell length $=8.3 \mathrm{~mm}$ (Figs. 3D-J, $\mathrm{L}, 9 \mathrm{~B})$. The holotype specimen is deposited with its host echiuran worm in the National Museum of Nature and Science, Japan.

Paratypes: Paratype specimens are deposited with their host echiuran worms in the National Museum of Nature and Science, Japan (NSMT-Mo 77015, Shell length $=6.8 \mathrm{~mm}$; NSMT-Mo 77016, Shell length $=6.3 \mathrm{~mm}$ ) and in the Smithsonian National Museum of Natural History, USA (USNM 1140542, Shell length $=5.5 \mathrm{~mm}$, Host: USNM 1140543), respectively.

Type locality: Intertidal gravelly coral-sand flat at Nezebu, Amami-Ohshima Island, Kagoshima Prefecture, Japan, $28^{\circ} 22^{\prime} \mathrm{N}, 129^{\circ} 25^{\prime} \mathrm{E}$.

Diagnosis: Shell small, ovate-trigonal, equivalve, laterally inflated, with strong keel running from beak to posteroventral corner. Shell having small gape at antero-ventral corner and large slit-like gape at postero-dorsal margin.

Description: Shell length to $8.3 \mathrm{~mm}$. Shell relatively thick, ovate-trigonal, equivalve, laterally inflated, length/ height about 1.4, length/width about 1.6 (holotype); beak prosogyrous, situated at about $20 \%$ from anterior end; anterior end rounded; posterior end subtruncate; ventral margin straight; external surface of shell with coarse pustules and irregular, coarse, commarginal growth checks; shell having a strong carina running from beak to the antero-ventral corner; angle of a carina most prominent dorsally; carina stout, weakly nodulous; shell having small gape at antero-ventral corner and large slit-like gape at postero-dorsal margin, even when valves are tightly closed; external ligament thin and very short on a short sturdy nymph; internal ligament thick, seated in an oblong, horizontal groove posterior of the beak; right valve with one prominent, antero-ventrally projecting cardinal (Fig. 3E); left valve with one ventrally projecting cardinal (Fig. 3F); both right and left valves having relatively wide escutcheon (Fig. 3L).

Anatomy: Both anterior and posterior adductor muscles ovate, subequal (Fig. 9B); the posterior adductor slightly larger than the anterior; the posterior part of the mantle having very short inhalant and exhalant siphons; both outer and inner demibranches present; the outer demibranch smaller than the inner; ctenidia joined anteriorly to inner and outer labial palps. Mantle edge smooth anteriorly and ventrally but with numerous, small, well-developed tentacles posteriorly 
Table 2. List of symbiotic organisms observed in echiuran burrows, showing host echiuran species, number of burrow observed, symbiotic rate, and mean number (with standard error) of individuals per burrow.

\begin{tabular}{|c|c|c|c|c|c|c|}
\hline Locality & Host echiuran species & $\begin{array}{c}\text { No. of } \\
\text { burrows } \\
\text { observed }\end{array}$ & Symbiont species & Class: Family & $\begin{array}{l}\text { Symbiotic } \\
\text { rate (\%) }\end{array}$ & $\begin{array}{c}\text { Mean }( \pm \mathrm{SE}) \\
\text { per burrow }\end{array}$ \\
\hline \multirow[t]{4}{*}{ Kure } & Ikedosoma gogoshimense & 34 & Macromphalus tornatilis & Gastropoda: Vanikoridae & 26.5 & $0.47 \pm 0.16$ \\
\hline & & & Basterotia gouldi & Bivalvia: Sportellidae & 64.7 & $2.06 \pm 0.55$ \\
\hline & & & Pinnixa sp. & Brachyura: Pinnotheridae & 2.9 & $0.03 \pm 0.03$ \\
\hline & Thalassema fuscum & 2 & Basterotia gouldi & Bivalvia: Sportellidae & 50.0 & $0.50 \pm 0.50$ \\
\hline \multirow[t]{4}{*}{ Amami-Ohshima Is. } & Ochetostoma erythrogrammon & 69 & Unidentified limpet & $\begin{array}{l}\text { Gastropoda: } \\
\text { Phenacolepadidae }\end{array}$ & 2.9 & $0.03 \pm 0.02$ \\
\hline & & & Basterotia carinata & Bivalvia: Sportellidae & 13.0 & $0.14 \pm 0.05$ \\
\hline & & & Unidentified scale worm & Polychaeta: Polynoidae & 4.3 & $0.04 \pm 0.02$ \\
\hline & & & Alpheus barbatus & Caridea: Alpheidae & 80.0 & $0.82 \pm 0.05$ \\
\hline
\end{tabular}

around the inhalant and exhalant pallial apertures. Digestive gland brown, anterior to white gonad which occupies the middle of the visceral mass; antero-ventral side of the mantle having one aperture through which the foot is extended; foot having byssal gland with fine, transparent byssal threads. Rectum with several compact faecal pellets; the ventral mantle margin attached by several small juveniles.

Biology: Symbiotic in the burrow of Ochetostoma erythrogrammon.

Distribution: Only known from Amami-Ohshima Island, southern Japan.

Etymology: From the Latin carina meaning keel, carinata meaning keeled in reference to the prominent keel running along the central slope of the posterior part of bivalves.

Remarks: The holotype of Basterotia carinata resembles that of Basterotia (Anisodonta) caledonica in having an equivalve, wedge-shaped shell. However, the holotype of $B$. carinata remarkably differs from that of $B$. caledonica in having an extremely prominent carina running along the central slope of both the right and left valves (Fischer, 1886). This does not indicate that the holotype of $B$. caledonica is ontogenetically less developed than that of $B$. carinata, because the former is 1.5 times larger than the latter (Fischer, 1886). In addition, the anterior adductor muscle of $B$. carinata is ovate, whereas that of $B$. caledonica is rounded (Fischer, 1886). On the other hand, the prominent carinae are similar to those of $B$. quadorata. However, $B$. quadorata have escutcheon almost only on the left valve (Coan, 1999), whereas $B$. carinata are equivalve, having equally-sized escutcheons on both the right and left valves. In addition, $B$. carinata is relatively horizontally longer than $B$. quadorata (the height/length ratio of $B$. quadorata is about $1.1: 1$, whereas that of $B$. carinata is $1.4: 1$ ) (Coan, 1999; this study).

\section{DISCUSSION}

\section{Commensalism of Basterotia bivalves with echiuran worms}

Our field surveys demonstrated that two species of Basterotia were symbiotic with specific echiuran species, which were burrow-dwelling deposit-feeders found in gravelly mud or coral-sand flats. Although the association of two other Basterotia species with annelids or echiurans has been briefly suggested (Kay, 1979; Anker et al., 2005), to our knowledge the present study is the first report of tight association between Basterotia bivalves and burrow-dwelling echiurans.

In our surveys, Basterotia bivalves were found embedded in burrow walls with their posterior aperture gaping to the burrow lumen (Figs. 2E, 3D, 4). The postures of the bivalves suggested that they utilized the water pumped through the tunnels by the echiuran hosts. In addition, the burrows of echiurans provide the bivalves with safe sites protected from predation pressure and environmental stresses, such as desiccation and severe fluctuations in temperature and salinity. Conversely, the effect of bivalves on host echiurans is little known. Considering the Basterotia bivalve is a filter feeder and was nearly entirely embedded in the burrow wall, any deleterious effect of the bivalves on the hosts would seem to be small. At least, negative effects of the number and size of symbiotic bivalves on the biomass volume of hosts were not detected (Figs. 6, 7). These results suggest that the relationship between echiurans and bivalves may be commensal.

\section{Morphological and ecological adaptations to symbiotic association with echiurans}

Recent molecular phylogenetic analysis suggests that Basterotia belongs to Galeommatoidea, most members of which have commensal relationships with various invertebrates (Campbell, 2000; Taylor et al., 2007; Gribet and Distel, 2003). However, Basterotia bivalves have several morphological characters quite different from those of other galeommatoidean bivalves. Perhaps, these characters may be the result of adaptation or specialization to their unique symbiotic associations with echiuran worms. Here, we discuss the relationships between such morphological characters of Basterotia bivalves and their symbiotic association with echiuran worms.

For symbiotic organisms in echiuran burrows, position and posture in the burrow are important because the inside of the burrow is persistently disturbed by the host's peristaltic activity (Anker et al., 2005). Basterotia bivalves are almost completely embedded into the burrow wall, and their posterior apertures gape into the burrow lumen (Fig. 4). This posture makes it possible for them to safely utilize the water currents created by the host by reducing the exposure of 
their body and friction with host echiurans. To achieve this posture, the posterior position of the inhalant siphon is necessary. Basterotia differs from other galeommatoidean species in having a posterior inhalant siphon (Coan, 1999). This morphological trait is considered as a pre- or postadaptation to life in echiuran burrows. The symbiotic life of Basterotia is very similar to that of Cryptomya californica (Myidae), which is a small bivalve distributed along the Pacific coast of the Americas from Alaska to Peru. This bivalve species also lives embedded in the tunnel wall of other burrowing animals, such as thalassinidean shrimps, annelids, and echiurans (Urechis caupo), and protrudes its extremely short siphon into the burrow cavity for feeding and respiration (Lawly, 1978; MacGinite, 1935; Peterson, 1977; Wicksten, 1978; Yonge, 1951). The extremely short siphon of Cryptomya is a unique trait among the close relatives of Myidae and is considered as an adaptation to symbiotic life in the burrow (Lawly, 1978; Yonge, 1951). Similarly, Basterotia also have very short siphons (Figs. 2J, 3L, 9). However, the Basterotia siphons may have been pre-adapted to symbiotic life, as most members of Galeommatoidea have very short siphons, or lack the siphon entirely (Ponder, 1998).

Other galeommatoideans that live in echiuran burrows, e.g., Pseudopythina ochetostomae and Scintilla thalassemicola, are characterized by their very flattened shells (Habe, 1962; Morton and Scott, 1989). Given that they cling closely to the burrow wall or host's body, their flattened shell may be an adaptation to reduce the friction between the burrow wall and the host's body. In contrast, the shells of Basterotia become laterally inflated as they grow (Fig. 8B, D). This is probably because Basterotia bivalves are embedded in the narrow interspace between mud-embedded pebbles and the burrow lumen. Such a posture in the burrow causes morphological constraint, as the bivalves must grow not proportionately, but only laterally. Contrasting differences in shell morphology between Basterotia and other galeommatoideans living in the echiuran burrow may reflect the result of differential adaptation to symbiotic association with echiuran worms.

In addition, the posterior parts of the shells in $B$. gouldi are remarkably thick (Fig. $2 \mathrm{~F}$ ) and are reinforced by developed thick carina in $B$. carinata (Fig. $3 \mathrm{H}, \mathrm{J}, \mathrm{L}$ ). In the present study, these parts were seen to slightly protrude into the burrow lumen and to interface with the host echiurans (Figs. $2 E, 3 D, 4)$. Therefore, these morphological traits are considered to be adaptations for withstanding the pressure caused by the host's undulating movement.

\section{Host preference}

Symbiotic association with echiurans is also known in Pseudopythina ochestostomae, a small bivalve species living in the burrow of $O$. erythrogrammon and $L$. sorbillans in Hong Kong and the Ryukyu Islands (Kosuge et al., 2003; Morton and Scott, 1989). This bivalve species belongs to Galeommatoidea and has completely lost its siphon (Morton and Scott, 1989). Although Basterotia and P. ochetostomae occupy similar ecological niches, they have different host preferences. $P$. ochetostomae is frequently found in the burrow of L. sorbillans (Kosuge et al., 2003), whereas Basterotia has never been found in burrows of $L$. sorbillans
(Kosuge et al., 2003; Goto, unpublished data). L. sorbillans extends its proboscis a great distance from the burrow entrance onto the surface of tidal flats and transports minute organic particles into its mouth through ciliate movements on the proboscis surface. The feeding habits of this echiuran suggest that the water current created by the host in the burrow is weak. Conversely, $O$. erythrogrammon and $I$. gogoshimesne powerfully inhale and exhale water in the burrow, thereby creating strong water currents through the burrow (Supplemental material online). Perhaps such strong water currents are necessary for the filter feeding of Basterotia, but not for that of $P$. ochetostomae.

\section{Reproductive biology}

Some members of Galeomattoidea show size-dependent sex change or protandrous consecutive hermaphroditism (Fox et al., 2007; Goto et al., 2007). Considering the size distribution of male and female bivalves recorded in this study (Fig. 10), Basterotia appears to change sex. B. gouldi changed sex from male to female when 8-10 mm long (Fig. 10). Some individuals at intermediate sizes between males and females did not exhibit any gonadal development. Such individuals may be intermediates in the process of changing sex from male to female.

Some galeommatoidean species are known to brood veligers or juveniles in the mantle cavity (Kato and Itani, 1995; Lützen and Nielsen 2005). In this study, we found that the largest $B$. gouldi female harbored hundreds of veligers in the ctenidium (Fig. $2 \mathrm{G}, \mathrm{H}$ ), and that mature individuals of $B$. gouldi and $B$. carinata brooded several juveniles in the ventral mantle margin (Figs. 2I, 3K, 9). Although the juvenilebrooding habit is known in two Basterotia species (Coan, 1999; Ponder, 1971), the veliger-brooding habit of Basterotia is reported for the first time in this study. In addition, we collected juveniles from the ventral margin of a mature male. This suggests that brooded juveniles may contain individuals that reattach to mature individuals after being released from the brooding female.

\section{The symbiont community in echiuran burrows}

To date, the only known commensal of Ikedosoma has been a snapping shrimp, Alpheus barubatus, collected from Ikedosoma sp. in Taiwan (Tzeng and Cheng, 1992), whereas no commensals were found in the burrows of $T$. fuscum in Hong Kong (Morton and Morton, 1983). In the present study, we recorded $B$. gouldi, $M$. tornatilis, and Pinnixa sp. as symbionts of $I$. gogoshimense, and B. gouldi as a symbiont of $T$. fuscum (Table 2). The small gastropod $M$. tornatilis was often found on pebbles embedded in burrow walls, suggesting that it occupies a relatively similar ecological niche to that of $B$. gouldi. The body of Pinnixa sp. is horizontally elongated, a body shape typically found in symbiotic crabs dwelling in echiuran burrows (Anker et al., 2005). In the Seto Inland Sea, three species of crabs, Sestrostoma balssi, Sestrostoma toriumii, and Pseudopinnixa carinata, were collected from the U-shaped burrows of Urechis unicinctus (Itani et al., 2005). However, we did not find these symbiotic organisms in Ikedosoma or Thalassema burrows.

The burrows of $O$. erythrogrammon have been surveyed in Hong Kong, the Ryukyu Islands, and Venezuela (Anker et 
al., 2005; Kosuge et al., 2003; Morton and Morton, 1983; Nomura, 2000). The burrows are inhabited by various organisms, such as the small bivalve $P$. ochestostomae, the small crab Mortensenella forceps, the small snail Sigaretornus planus, the snapping shrimp A. barbatus, by an unidentified scale worm in Hong Kong and the Ryukyu Islands (Kosuge et al., 2003; Morton and Morton, 1983; Nomura, 2000), and by the small crab, Pinnixa sp. aff. chaetopterana, Pinnixa sp. aff. monodactyla, and the small bivalve, Basterotia sp., in Venezuela (Anker et al., 2005). In this study, we found a snapping shrimp, $A$. barbatus, the small bivalve $B$. carinata, an unidentified scale worm, and a phenacolepadid limpet in the burrows of $O$. erythrogrammon at Amami-Ohshima Island (Table 2). An extensive geographic comparison of symbiont communities may reveal whether these associations are maintained throughout the tropical waters of the world.

\section{ACKNOWLEDGMENTS}

We are grateful to Amami Wildlife Conservation Center for logistic support during fieldwork; T. Okamoto for assistance with figure preparation; and A. Kawakita and two anonymous referees for comments that improved this manuscript.

\section{REFFERENCES}

Anker A, Murina GV, Lira C, Vera Caripe JA, Palmer AR, Jeng MS (2005) Macrofauna associated with echiuran burrows: a review with new observations of the innkeeper worm, Ochetostoma erythrogrammon Leuckart and Rüppel, in Venezuela. Zool Stud 44: $157-190$

Campbell DC (2000) Molecular evidence on the evolution of the Bivalvia. In "The Evolutionary Biology of the Bivalvia" Ed by EM Harper, JD Taylor, JA Grame, Geological Society, London, Special Publication 177, pp 31-46

Coan EV (1999) The eastern Pacific Sportellidae (Bivalvia). Veliger 42: $132-151$

Fischer P (1886) Nouvelles observations sur le genre Eucharis, Recluz. Jornal de Conchyliologie 34: 193-203

Fox TH, Jespersen $\AA$, Lützen J (2007) Sperm transfer and reproductive biology in species of hermaphroditic bivalves (Galeommatoidea: Montacutidae). J Morphol 268: 936-952

Giribet G, Distel DL (2003) Bivalve phylogeny and molecular data. In "Molecular systematics and Phylogeography of Mollusks" Ed by C Lydeard, D Lindberg, Smithonian Institution Press, Washington DC, pp 45-90

Goto R, Hamamura Y, Kato M (2007) Obligate commensalism of Curvemysella paula (Bivalvia: Galeommatidae) with hermit crabs. Mar Biol 151: 1615-1622

Habe T (1962) Achasmea thalassemicola sp. nov., a new commensal bivalve found in an echiuroid, Thalassema mucosum lkeda. Venus 22: 117-119

Ikeda I (1904) The Gephyrea of Japan. J Coll Sci Imp Univ Tokyo 20: $1-87$

Itani G, Izichi M, Ueda H (2005) Crab species collected from the burrows of Uechis unicinctus in Hiuchi-nada, the central Seto Inland Sea, Japan. Cancer 14: 1-4 (in Japanese with English abstract)

Jones CG, Lawton JH, Shachak M (1994) Organisms as ecosystem engineers. Oikos 69: 373-386

Jones CG, Lawton JH, Shachak M (1997) Positive and negative effects of organisms as physical ecosystem engineers. Ecology 78: $1946-1957$
Kato M, Itani G (1995) Commensalism of a bivalve, Peregrinamor ohshimai, with a thalassinidean burrowing shrimp, Upogebia major. J Mar Biol Assoc UK 75: 941-947

Kawaguti S (1971) Electron microscopy on blue-green algae in the body-wall of an echiuroid, Ikedosoma gogoshimense. Biol J Okayama Univ 14: 67-74

Kay EA (1979) Hawaiian Marine Shells. The Bernice P. Bishop Museum, Honolulu, Hawaii, Special Publication 64

Kosuge T, Kubo H, Nishikawa T (2003) Distribution and ecology of Pseudopythina ochetostomae (Mollusca, Bivalvia, Lasaeidae) dwelling in burrows of echiurans in the Ryukyu Islands, southern Japan. Biol Mag Okinawa 41: 7-13 (in Japanese with English abstract)

Lawly EV (1978) Cryptomya californica (Conrad, 1837): observations on its habitat, behavior, anatomy, and physiology. The Veliger 30: 46-54

Lützen J, Nielsen C (2005) Galeommatid bivalves from Phuket, Thailand. Zool J Linn 144: 261-308

MacGinitie GE (1935) Ecological aspects of a California marine estuary. Am Midl Nat 16: 629-765

Morton B, Morton J (1983) The sea-shore ecology of Hong Kong. Hong Kong Univ Press, Hong Kong

Morton B, Scott PH (1989) The Hong Kong Galeommatacea (Mollusca: Bivalvia) and their hosts, with description of new species. Asian Mar Biol 6: 129-160

Nickell LA, Atkinson RJA, Hughes DJ, Ansell AD, Smith CJ (1995) Burrow morphology of the echiuran worm Maxmuelleria lankesteri (Echiura: Bonelliidae), and a brief review of burrow structure and related ecology of the Echiura. J Nat Hist 29: 871-885

Nomura K (2000) Host and colour variation of Alpheus barbatus Coutière (Crustacea, Alpheidae) in Japan. Biol Mag Okinawa 38: 59-64 (in Japanese with English abstract)

Peterson $\mathrm{CH}$ (1977) Competitive organization of the soft-bottom macrobenthic communities of southern California lagoons. Mar Biol 43: 343-359

Ponder WF (1971) Some New Zealand and subantarctic bivalves of the Cyamiacea and Leptonacea with descriptions of new taxa. Records of the Dominion Museum 7: 119-141

Ponder WF (1998) Superfamily Galeommatoidea. In "Mollusca: The Southern Synthesis" Ed by PL Beesley, GJB Ross, A Wells, CSIRO Publishing, Melbourne, Australia, pp 316-318

Rogers AD, Nash RDM (1996) A new species of Ochetostomae (Echiura, Echiuridae) found in the Azores with notes on its ecology. J Mar Biol Assoc UK 76: 467-478

Schembri PJ, Jaccarini V (1978) Some aspects of the ecology of the echiuran worm Bonellia viridis and associated infauna. Mar Biol 47: $55-61$

Stephen AC, Edmonds SJ (1972) The phyla Sipuncula and Echiura. Trustees of the British Museum (Nat. Hist.), London

Taylor JD, Williams ST, Glover EA, Dyal P (2007) A molecular phylogeny of heterodont bivalves (Mollusca: Bivalvia: Heterodonta): new analyses of $18 \mathrm{~S}$ and $28 \mathrm{~S}$ rRNA genes. Zool Scripta 36: 587-606

Tzeng MS, Cheng YS (1992) Seashore life in the east coast. Guide to the seashore life in the east coast national scenic area of Taiwan. Taiwan

Wicksten MK (1978) Checklist of marine molluscs at Coyote Point Park, San Francisco Bay, California. Veliger 21: 127-130

Yonge CM (1951) Studies on Pacific coast molluscs: I. On the structure and adaptations of Cryptomya californica Conrad. University of California Publications in Zoology 55: 395-400

(Received April 21, 2010 / Accepted August 13, 2010) 